\title{
Article \\ The Effect of Port Gate Location and Gate Procedures on the Port-City Relation
}

\author{
Marina Zanne *(D), Elen Twrdy (D) and Bojan Beškovnik (D) \\ Faculty of Maritime Studies and Transport, University of Ljubljana, 1000 Ljubljana, Slovenia; \\ Elen.Twrdy@fpp.uni-lj.si (E.T.); bojan.beskovnik@fpp.uni-lj.si (B.B.) \\ * Correspondence: marina.zanne@fpp.uni-lj.si; Tel.: +386-5-6767-211
}

\begin{abstract}
Ports are important hubs that have positive impacts on the regions they serve, but they also pose some challenges that need to be addressed. Many ports around the world have aligned their development strategies with the concept of green growth; however, the green and efficient performance of ports does not only depend on the port management itself; some elements need to be negotiated and approved by local and national governments. One of such elements is road port access. We investigated the impact of port gate location and port gate procedures on port's performance by examining the case of the Adriatic port of Koper, the only Slovenian international cargo port. We found that significant external costs are incurred due to a non-optimized situation caused by the lack of coordination and cooperation on all levels, although the port of Koper is one of European core ports. Further, delayed digitalization of port gate procedures caused by port management adds to degradation of port city relations.
\end{abstract}

Keywords: port gates; gate procedures; port-related truck traffic; external costs; port-city relation

Citation: Zanne, M.; Twrdy, E.; Beškovnik, B. The Effect of Port Gate Location and Gate Procedures on the Port-City Relation. Sustainability 2021, 13, 4884. https://doi.org/10.3390/ su13094884

Academic Editor: Antonio Comi

Received: 19 March 2021

Accepted: 22 April 2021

Published: 27 April 2021

Publisher's Note: MDPI stays neutral with regard to jurisdictional claims in published maps and institutional affiliations.

Copyright: (c) 2021 by the authors. Licensee MDPI, Basel, Switzerland. This article is an open access article distributed under the terms and conditions of the Creative Commons Attribution (CC BY) license (https:// creativecommons.org/licenses/by/ $4.0 /)$.

\section{Introduction}

International trade, which has been largely liberalized for several decades, makes it possible to alleviate a fundamental economic problem, namely, resource scarcity, but only if it is efficient. It can be said to be efficient if the logistics chain between the point of production and the point of consumption is cost-effective and time-efficient. Ports play an important role in this regard, handling about 11 billion tons of cargo per year [1]. Ports are complex systems, each with its own history and development path. On the one hand, they directly support international trade, and thus the economic growth and development of countries; on the other hand, they also employ many people, either directly or indirectly.

Ports compete in a free market where many factors contribute to their success, such as port infrastructure and equipment, port efficiency, frequency of calls, port location, hinterland connectivity, port costs, port reputation, etc. (e.g., [2,3]). Among these, hinterland accessibility has recently been recognized as the second most important factor, right after port costs [4,5]. Notteboom and Rodrigue [6] see the development of hinterland networks as a new dimension for competition between seaports. Hinterland transport links are a matter for local, regional, and national authorities, while the port itself can partly influence traffic flows around the port, for example, with appropriate design and capacity of port gates, optimization of gate procedures, or the use of extended gates.

Increasing globalization, new technologies, and ever larger ships have added to the pressure on ports. Ports that want to remain competitive have to adapt their offer to the demand with technical-technological and organizational approaches and ensure high productivity, low costs, and fast handling of ships. While for a long time the development of ports was based solely on economic considerations, with the aim of getting back the money invested as quickly as possible, more recently the importance of the environment and relation with the local community have been emphasized. Ports require huge areas of coastal land for their operation, which cannot then be used for other purposes. Moreover, 
their operation, i.e., cargo handling, ships calling at the port and traffic serving the port hinterland, causes many negative impacts perceived as noise, emissions, water quality degradation, soil pollution, waste production, biodiversity loss, land use impacts, traffic impacts (congestion) and other impacts such as visual impacts, odor, or dust [7]. Therefore, the traditionally strong link between ports and cities started to fade $[7,8]$. Ports that want to prosper must therefore base their development on responsibility towards the environment and the local community. Many ports have thus developed social responsibility strategies [9] that include environmental management systems (EMS) and energy management systems (EnMS), and defined a list of Environmental Performance Indicators (EPIs) supported by monitoring systems with real-time information for the interested public (e.g., [10-13]).

The authors focus on port-related truck traffic in port cities resulting in increased congestion, lower air quality, and deteriorating roads. Using the port of Koper as an example, the authors attempt to define the external costs of freight traffic as a function of port gate location and administrative port gate procedures.

The port of Koper presents a critical infrastructure for the Republic of Slovenia [14] and important transport node for large part of Central Europe which was recognized also by the European Commission that has classified it as one of 83 core Trans-European Transport Network (TEN-T) ports and put it on two corridors, namely, Baltic-Adriatic and Mediterranean corridor.

To remain competitive and able to provide smooth operations, ports need to undergo constant development of all important port elements that is sea side, yard side, and land side, in a harmonized manner. This includes also the capacitation and location of port gates and adjustment of port gate procedures, which requires a systematic approach and the inclusion of different stake-holders in decision-making. Particular care has to be given when the ports are located close to the cities when port-related traffic interferes with regular city traffic on daily basis and is further emphasized in small port cities like Koper is.

By presenting a thorough analysis of a selected case, we aimed to prove that complex decisions must take into account different, often conflicting aspects and that external costs should be included in the decision-making process. Local and national authorities did not follow the progressive and environmentally friendly ideas of Luka Koper, the management company of the Port of Koper, regarding port gates and road port access. Urban planning and port planning were not coordinated, and compromises were not reached, resulting in wasted resources, potentially reduced quality of port services, and leaving port-related truck traffic on the city streets, which in turn affects the local community's opinion on port activities.

The paper is divided into seven sections. Section 2 provides a literature review on portrelated negative externalities and measures that can be taken by port authorities to reduce port-related traffic. Section 3 briefly explains the methodology used. Section 4 presents the port of Koper. Section 5 is devoted to the calculations of port related externalities. Section 6 brings the discussion and Section 7 the conclusions.

\section{Literature Review}

Ports need to develop their sea side (berths and quays), yard side (storage areas, internal transport, and internal operations) and land side (gates, and delivery/receiving procedures) synchronously; developing one and neglecting the other(s) may lead to irrational use of resources while not optimising the overall throughput capacity of the port. Typically, the development of a port is planned and overseen by the port authority, which is usually a public corporation under a municipal, regional, or state authority. The governance model influences the autonomy of port authorities in decision-making and their funding options [15]. Port authorities invest mainly in port infrastructure and port facilities, but have recently become active in the hinterland as well [16].

Nowadays, port authorities have to take care of the return on invested funds and the development of the port as a whole, while maintaining a good relationship with the 
local community and improving the port's environmental performance. They need to look for sustainable solutions and continuously balance environmental impacts and economic interests [17]. There is much literature dealing with the greening of port activities; however, little attention has been paid to the role of the port in reducing negative externalities in its hinterland [18].

Moreover, research mainly focuses on ports or cities separately, rather than combining the two [19], although many ports have remained close to cities, and with the growth of port activities, the need to transport goods through urban zones often increases, negatively affecting traffic and urban life, and creating an even wider gap between the concepts of urban development and those of port development [20].

Market changes have led to the need for ports to be part of logistics networks [21], where fast clearance of ships and fast distribution of cargo are crucial. The quality of hinterland connections has therefore become one of the key aspects for port selection $[22,23]$ and the competitiveness of ports is increasingly influenced by the process of creating trade corridors, where national involvement is clearly required [24]. However, port authorities, together with local authorities, must try to reduce port-related truck traffic in port cities, as the majority of goods handled in ports are still transported by road. In fact, even the ports with the highest shares of non-truck hinterland traffic barely manage to achieve more than half of their traffic by means other than trucks [24], resulting in many negative impacts as can be seen in Table 1 . This problem is further underscored by the fact that there is a large fragmentation of road freight sector, leading to a large number of empty trips and more congestion on the roads, as well as more emissions and ultimately higher overall transportation costs and a less competitive supply chain [25]. For example, in a well-developed Vancouver port, only about $18 \%$ of truck movements are part of a double transaction [26].

Table 1. Negative impacts/externalities of truck traffic.

\begin{tabular}{|c|c|}
\hline Author(s) & Research Topic \\
\hline [27] & $\begin{array}{l}\text { Road traffic is a dominant source of nitrogen dioxide }\left(\mathrm{NO}_{2}\right) \text { and a significant source of primary particulate matter } \\
\left(\mathrm{PM}_{10}\right) \text {, but not of } \mathrm{PM}_{2.5} \text {. }\end{array}$ \\
\hline [28-31] & $\begin{array}{l}\text { Alternative fuels for heavy trucks, like biodiesel blends, hydrogen or LNG, and the use of connected vehicle } \\
\text { technology or truck platooning can produce lower emissions. }\end{array}$ \\
\hline [32-35] & $\begin{array}{l}\text { Emissions rates are a function of speed. Shifting trucks from daytime to night-time or from peak to off-peak period } \\
\text { can reduce traffic congestion and reduce air pollution (extreme and average concentrations). }\end{array}$ \\
\hline [36-38] & $\begin{array}{l}\mathrm{PM}, \mathrm{NO}_{2} \text {, carbon monoxide (CO), black smoke, benzene, polycyclic aromatic hydrocarbons (PAHs), and metals } \\
\text { from heavy-duty trucks impact especially elderly and very young people and those living/working/attending } \\
\text { school close to main roads, with cardiopulmonary diseases. }\end{array}$ \\
\hline [39] & $\begin{array}{l}\text { The costs of urban congestion include five quantifiable elements, namely the price of the time lost, operating costs } \\
\text { (fuel and maintenance), the financial costs attributable to specific accidents due to congestion, price of noise } \\
\text { pollution, cost and damage from extra emissions, and non quantifiable elements like attractiveness of the city for } \\
\text { investments. }\end{array}$ \\
\hline [40] & $\begin{array}{l}\text { Congestion affects costs and has important strategic impacts on inter-port and inter-route competition and is } \\
\text { especially important in the logistics for container shipping. }\end{array}$ \\
\hline [41] & Development of the instrument for uniform quantification of road congestion costs. \\
\hline [42] & $\begin{array}{l}\text { Empty truck trips, caused by a lack of coordination among truckers, are responsible for a significant share of } \\
\text { port-related emissions. }\end{array}$ \\
\hline$[43,44]$ & $\begin{array}{l}\text { Larger traffic volumes, higher speeds, greater numbers of trucks and their weight, or any faulty vehicle part (eq. } \\
\text { mufflers) increase the loudness of traffic related noise. Heavy vehicles generate between } 80 \text { and } 110 \mathrm{~dB} \text { of noise; } \\
\text { noise depends also on pavement structure and condition. Traffic noise affects greatly health and well-being of } \\
\text { people. }\end{array}$ \\
\hline [45-47] & $\begin{array}{l}\text { Many factors influence the impact of vehicles on the pavement. The dynamic load of heavy vehicles accelerates the } \\
\text { destruction of the pavement/roads. It is possible to develop a damage model for the determination of damage } \\
\text { caused by different vehicles. }\end{array}$ \\
\hline
\end{tabular}


Digitalization and sustainability are the megatrends that will change the transport and logistics industry in the future [30]. This also leads to a redefinition of the importance of port gates in the logistics chain and their impact on port-city transport.

The problem of gate performance and port-related truck traffic can be addressed in different ways, with measures ranging from operational and technological to layout changes and changes in the way the port operates, as shown in Table 2. Not all measures are appropriate or applicable to all ports. The types of measure that could be taken by the port authority depend mainly on the physical characteristics of the port, which include port turnover in terms of volume and structure, port layout and proximity to the city [48], the financial situation and the position of the port in the broader context (e.g., regional, national or TEN-T port).

Table 2. Measures that can be taken by port authorities to reduce port-related truck traffic in port cities.

\begin{tabular}{|c|c|}
\hline Author(s) & Research Topic \\
\hline [49-52] & $\begin{array}{l}\text { Truck appointment system (TAS) or Vehicle Booking System (VBS) based on static or dynamic methods can reduce } \\
\text { truck queuing time at the terminals gate or on the yard and optimize the appointment quota as well as trucking } \\
\text { company performance, especially when trucking companies and terminals collaboratively determine truck } \\
\text { schedules and appointments for truck arrivals. }\end{array}$ \\
\hline$[42,53]$ & TAS to reduce empty rides and port related emissions. \\
\hline [54] & A multi-server queuing model to measure gate congestion and to quantify costs of congestion at the gates. \\
\hline$[7,55,56]$ & $\begin{array}{l}\text { Longer gate opening hours need to be coordinated with other chain partners but can relieve city and port } \\
\text { congestion, although cases show that additional opening hours can be economically unfeasible and the upgrade in } \\
\text { the form of flexible opening hours seems more adequate }\end{array}$ \\
\hline$[53,57]$ & $\begin{array}{l}\text { Gate layout efficiency differences between pooled and non-pooled queuing strategies, and lane allocation methods } \\
\text { to relieve gate congestion. }\end{array}$ \\
\hline$[55,58-61]$ & $\begin{array}{l}\text { Gate automation and the use of sensors/cameras can increase utilization of existing space and diminish the need for } \\
\text { new areas as well as reduce traffic emissions; e.g., driver identification system (DIS), License plate identification } \\
\text { system (LPIS), Container number recognition system (CNRS), RFID for real-time monitoring and RFID chips into } \\
\text { the seals. }\end{array}$ \\
\hline [62-65] & $\begin{array}{l}\text { Extended gates can generate substantial benefits in terms of modal shift, relieved traffic from the city roads and port } \\
\text { gates, increased capacity of the port, logistics performance and regional development, while port drayage can be } \\
\text { optimized by different scheduling and routing algorithms as well as with introduction and support of cleaner } \\
\text { vehicles. }\end{array}$ \\
\hline$[24,66]$ & Peak pricing strategies to distribute traffic throughout the day. \\
\hline [67] & $\begin{array}{l}\text { The elimination of Improper Documents that cause congestion at port gates by setting a compulsory pre-gate } \\
\text { system or applying early registration procedures. }\end{array}$ \\
\hline [68] & $\begin{array}{l}\text { The use of tradable truck permits at multiterminal ports to improve TAS can yield the same efficiency as the perfect } \\
\text { colloboration (ie. all the terminals considered as a single company) would. }\end{array}$ \\
\hline
\end{tabular}

Source: Authors.

\section{Data and Methods}

The paper consists of a two-step research process.

First, we reviewed the literature on port authority actions to optimize port gate operations and reduce congestion in port cities. Then, we examined research on congestion costs and truck emissions. We used the following keywords: "port gates", "port gate procedures", "port-city relationship", "port related truck traffic", "port access roads", "extended gates", "truck appointment system", "congestion costs estimation", "truck emissions" and "pavement damage". We mainly used the Science Direct database and Google Scholar.

We proceeded with the case study, which focused on the port of Koper. Although case study methods can be perceived as controversial, especially single case studies as they cannot provide generalized assumptions, they are widely accepted in social sciences. The use of case studies is particularly present in the analysis of ports, as it allows for a detailed examination of the area or problem under study.

The port of Koper has a specific location; it is surrounded on two sides by residential areas and on the third side by a nature reserve. Normally, port authorities define the port's 
development strategy and regulate the relationship between the port and the city, but in Slovenia there is no port authority. The Port of Koper, the only Slovenian cargo port, has a particular management structure that does not fit any of the existing port management models; the Port of Koper is managed and operated by a single company Luka Koper combining private and public capital. Accordingly, it is to be expected that private and public interests may collide.

The research questions were formulated at the beginning of the study. The main research question was "How do the location of the port gates and the operations at the gates affect the relationship between the port and the city?" In addition, we wanted to investigate what external costs are generated by port-related traffic on the streets of Koper.

Interviews and discussions with Luka Koper key persons as well as document review were used to obtain the information that allowed a detailed analysis of the case study. We adopted a simplified approach to estimating external costs related to port traffic. There is no official data on the traffic structure on all road sections connecting the port of Koper, so we estimated the number of port-related trucks on the city's roads based on the port's throughput structure and land transport modal split for the period from 2008 to 2020 . Then, we approximated the level of congestion by observing the traffic on the main route from the highways to the port gates and used this approximation throughout the analysis period, although traffic conditions changed over time due to changes in the location of port gates and port gates procedures. Finally, we calculated the values of congestion costs and air pollution costs for Slovenia from the average values of marginal congestion and air pollution costs for the EU-28, as suggested in Updated Handbook on External Costs of Transport by Korzhenevych et al. [69].

\section{Koper-The Port-City Relation}

\subsection{The Port of Koper}

The port of Koper, the only Slovenian international cargo port, started its activity in December 1958 as a single-berth port with $135 \mathrm{~m}$ of quay. Since then, the port has developed into one of the most important North Adriatic ports; the port of Koper holds the leading position in container traffic in the Adriatic Sea and is second among Mediterranean ports in terms of car transhipment.

Today, this multipurpose port has twelve specialized terminals with $3300 \mathrm{~m}$ of quay and 26 berths and handles about 20 million tons of cargo, and as such (if only throughput is considered) can be considered a small port [70] or a medium-sized port [21]. Seventy kilometers of roads and thirty kilometers of railways connect all terminals to the public transport infrastructure.

Ports must align their operations with overall sustainability goals, i.e., ensure optimal economic and social outcomes while causing minimal environmental damage [1]. Typically, larger ports in developed countries pay more attention to achieving sustainable growth and maintaining good relations with local communities (e.g., [71,72]). This also appears to be true for ports located near dense urban areas (e.g., $[73,74])$.

Despite its relatively small size and the specificity of its organization, the port of Koper is designed and operated according to sustainable principles. Luka Koper manages the entire port area, which enables the implementation of an environmental protection system at all terminals and in all activities. Luka Koper obtained ISO 14,001 in 2000, in May 2006 this standard was updated to ISO 14,001: 2004 and in 2017 to 14,001: 2015. Luka Koper received EMAS certification in 2010, and recently Luka Koper updated its environmental management system to meet the requirements of the energy efficiency standard ISO 50,001: 2018 [75]. In addition, Luka Koper has prepared its own environmental management system and has an environmental policy that refers to the guidelines of European Seaports Organization (ESPO).

Throughput of the port of Koper has in the analyzed period from 2008 to 2020 as can be seen in Figure 1. In 2008, the average cargo volume per ship was 7207 tons, while in 2020 it grew to 13,624 tons, although throughput has fallen by more than 4.5 million tons 
since 2018. Such growth puts a strain on the port's internal organization and work safety, but also on the city's traffic and, consequently, on the environment. Moreover, the structure of transhipment has changed; the share of containers in total transhipment has more than doubled and reached $47.5 \%$ in 2020.

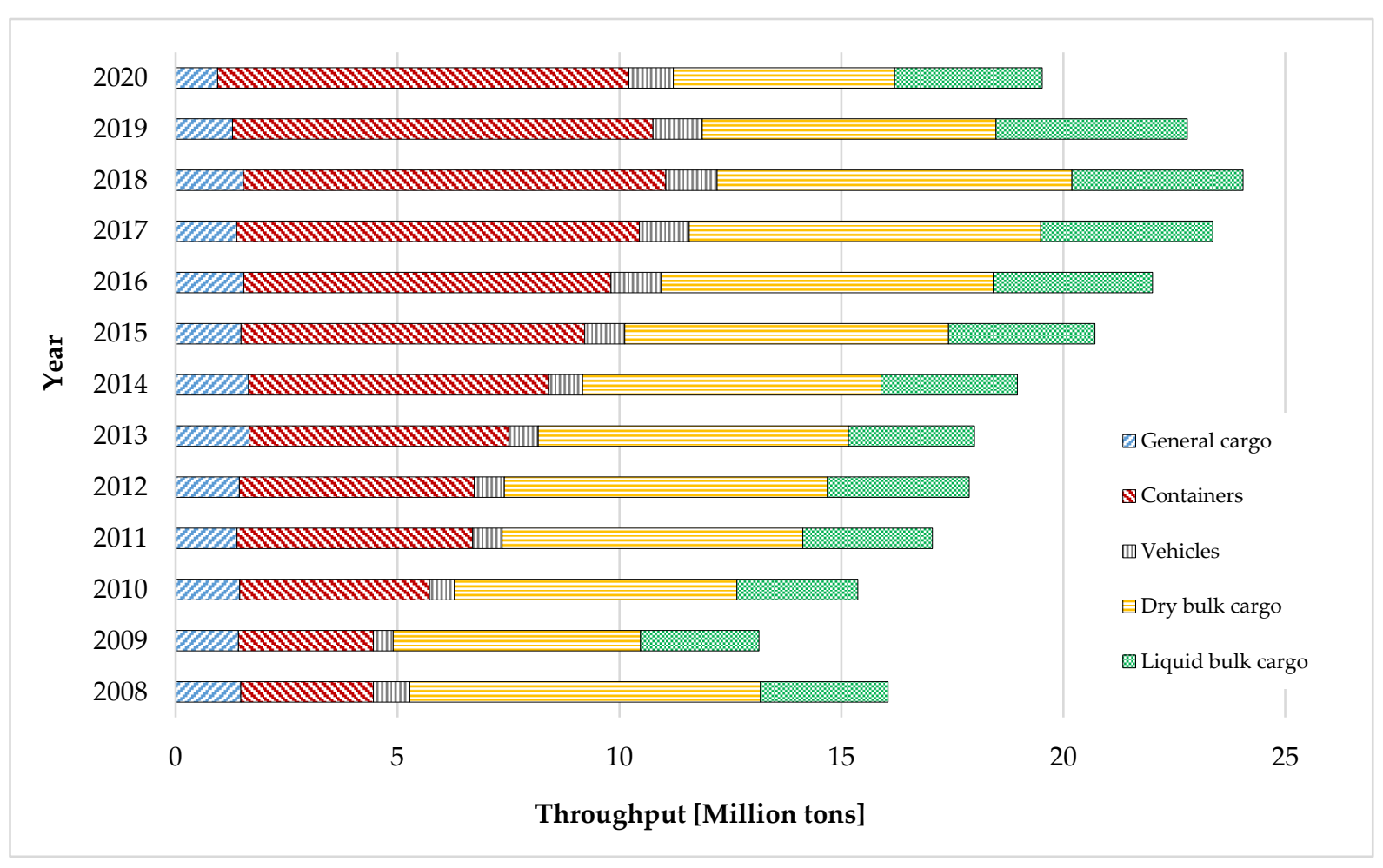

Figure 1. Total throughput in the port of Koper (in a million tons) in the period from 2008 to 2020. Source: authors, based on [76].

The port of Koper serves a wide hinterland that includes Slovenia, Croatia, Austria, northern Italy, Hungary, Switzerland, southern Germany, Czech Republic, Slovakia, Serbia, and marginally some other countries. These countries have good economic potential, which could be increased by moving the "blue banana" to the east. Moreover, the port of Koper is located on the corridor Baltic-Adriatic, which is considered as one of the most important trans-European road and railway axes. The North Adriatic Route represents the most convenient and environmentally friendly trade route connecting Central Europe with the Middle and Far East. Not surprisingly, Luka Koper has ambitious expansion plans worth around EUR 700 million. Accordingly, throughput is expected to increase from 27.4 to 35.1 million tons of cargo in 2030 [77] and from 37.5 to 49.9 million tons in 2040 [78], depending mainly on the quality and capacity of hinterland connections. Such growth would bring positive economic effects; however, it would also mean additional pressure on surrounding roads and habitat and lead to increased external costs of port-related traffic and a deterioration of the quality of life in the vicinity of the port, especially if not planned holistically [20].

\subsubsection{Socio-Economic Profile of the Municipality of Koper}

Some selected socio-economic indicators, presented in Table 3, suggest that living in the municipality of Koper offers some advantages in relation to other municipalities in Slovenia; mainly more employment opportunities and higher wages. This means that the port of Koper still acts as a driver of socio-economic development in the municipality and attracts new residents to the region. 
Table 3. The municipality of Koper shows better demographic and economic situation that the rest of Slovenia.

\begin{tabular}{|c|c|c|c|c|}
\hline & \multicolumn{2}{|c|}{2012} & \multicolumn{2}{|c|}{2019} \\
\hline & Koper & Slovenia & Koper & Slovenia \\
\hline Density of population (per $\mathrm{km}^{2}$ ) & 171 & 101 & 173 & 103 \\
\hline Total increase (per 1000 population) & 6 & 2 & 7.3 & 7.2 \\
\hline Net migration (per 1000 population) & 3 & 2.5 & 8.6 & 7.8 \\
\hline Employment/population ratio (\%) & 59 & 57 & 67.8 & 66.0 \\
\hline Registered unemployment rate (\%) & 9.8 & 12.0 & 7.1 & 7.7 \\
\hline Registered unemployment rate for men (\%) & 10 & 12 & 6.5 & 7.2 \\
\hline Registered unemployment rate for women (\%) & 10 & 13 & 7.8 & 8.4 \\
\hline Average monthly gross earnings (index, SI $=100)$ & 103 & 100 & 104.4 & 100 \\
\hline Average monthly net earnings (index, SI $=100$ ) & 103 & 100 & 103.8 & 100 \\
\hline Number of passenger cars (per 100 population) & 57 & 52 & 58.9 & 55.6 \\
\hline
\end{tabular}

Source: $[79,80]$.

Each year, Luka Koper conducts an opinion survey on citizens' perceptions of Luka Koper's attitudes toward environmental protection and the performance of its operations. It includes men and women of all ages from all parts of the city that may be affected by port operations. The overwhelming opinion $(89.0 \%)$ is that Luka Koper is successful or very successful as a business. Respondents believe that the biggest polluters of the local environment are port activities (28.8\%;26.8\% in 2018 and $14.3 \%$ in 2017), industry in Trieste (20.9\%; $26.7 \%$ in 2018 and $33.8 \%$ in 2017$)$ and road traffic $(27.5 \% ; 26.1 \%$ in 2018 and $25.6 \%$ in 2017). Nevertheless, only $10.2 \%(11.0 \%$ in 2018$)$ of the respondents consider that Luka Koper makes too little or hardly sufficient efforts to protect the environment $[81,82]$.

\subsubsection{Wider Economic Importance of the Port of Koper}

The port of Koper is an important source of jobs; a generous estimate shows that every million tons of cargo handled at the port generates 820 jobs and about EUR 60 million in services and products in the Slovenian economy [83]. Luka Koper generated an average of EUR 233 million in direct operating revenues and generated an average of EUR 735 million in indirect and induced operating revenues for the Slovenian economy in the period from 2009 to 2018 [84]. This means that every euro in port revenues generates another EUR 3.3 in revenues in other economic activities in Slovenia [85].

Luka Koper has a growing importance for the Slovenian and regional economy as well as for the transport-logistics sector itself. Port activities generated directly, indirectly and implicitly $0.8 \%$ of all jobs in Slovenia and over $15 \%$ in the coastal region. They generate $13.6 \%$ in the Slovenian transport-logistics sector [84]; indeed, more than 70 freight forwarding and shipping agencies operate in the port area alone and many road transport companies depend on port activities. There are several freight rail operators in Slovenia, but the most important remains Slovenian Railways-Freight (Slovenske železnice-Tovorni promet); more than half of the freight transported annually by Slovenian Railways trains is related to the operation of the Port of Koper.

The activities of the Luka Koper contributed to about 1.4\% to Slovenia's GDP in 2018, or about $1 \%$ of total value added in Slovenia; these figures were appropriately higher in the coastal region, where value added from the port and port-related activities reached a share of $17.6 \%$ (only $13.6 \%$ in 2009), and in the transport sector, where the share remained at $15.4 \%$ [84]. However, it is important to understand that the activities of ports generate multiplicative effects in trade, tourism, catering and financial services, etc. It is estimated that each ton of cargo transported through Slovenia brings EUR 20-30 into the Slovenian financial system [86].

\subsection{Modal Split of the Port of Koper}

About one-third of port of Koper's throughput is for the Slovenian market, and all the rest for foreign markets. The port is connected to the hinterland by a modern highway system and by an out-dated rail system. The average speed for freight trains is about 
$37 \mathrm{~km} / \mathrm{h}$ [87] and freight trains have an average delay of $94.7 \mathrm{~min}$ per $100 \mathrm{~km}$ [88], yet about $60 \%$ (59\% and 2019) of all goods from the port of Koper that are not transhipped (about $88 \%$ of the total) are transported by rail. This means that rail transported about 10.3 million tons in 2020 (11.8 million tons in 2019) and trucks about 7 million tons (8.2 million tons in 2019).

In 2020, 19,898 trains entered and exited the port, a decrease of $11 \%$ from 2019 and $14 \%$ from the record year of 2018; $40 \%$ of these trains were container trains. In 2018, the modal split for container land transport remained at 50:50, and in 2019, 52\% of all containers handled at the port were transported by rail. The port of Koper is connected to European centers by approximately 140 container trains per week, each of which can carry up to 80 TEUs.

The normal capacity for freight traffic on the existing rail line increased by almost 5 million tons after the reconstruction works in 2010-2016 and is now around 14.0 million tons per year; the averages for the Divača-Koper and Koper-Divača directions were 370 and 630 net tons per train, respectively [78].

In 2019, 337,940 trucks served the port. Slovenian highways have a nominal capacity of 66,000 vehicles per day. In recent years, the structure of traffic flows has changed; the share of trucks is higher, which has a negative impact on traffic flow and safety. However, from the point of view of efficiency of logistic chains through the port of Koper, the highway capacity is not (yet) questionable; the connection of the port to the highways and the traffic on the roads of Koper are.

The Slovenian transport system is integrated into the European transport corridors, which ensures the support and co-financing of missing sections and the provision of more modern and efficient transport solutions. Since 2013, the port of Koper has been positioned in two priority multimodal corridors: the Baltic-Adriatic and the Mediterranean corridor. The Port of Koper is defined as a core port for the European transport network, which qualifies it for co-financing of its hinterland access.

\section{Forecasted Modal Split for the Port of Koper}

The Slovenian railway network does not meet the requirements of TEN-T (train length $740 \mathrm{~m}$, axle load $22.5 \mathrm{t}$ and speed $100 \mathrm{~km} / \mathrm{h}$ ) even on corridor lines, which can be an important limiting factor for the growth of transhipment in the port of Koper. Apart from the single-track and heavily used Koper-Divača connection, the bottlenecks in the Slovenian railway network are the Ljubljana railway junction and the single-track lines Ljubljana-Jesenice and Maribor-Šentilj. The further development of the port of Koper is therefore highly dependent on the construction of the second track Koper-Divača and in general on the modernization of the Slovenian railway network.

If the second track is not built, rail freight traffic will not exceed 14 million net tons per year due to capacity constraints (Figure 2), and consequently the growth of the total throughput of the port of Koper will be slower, as the port will probably lose competitiveness in relation to other North Adriatic ports. Nevertheless, road transport, as the only substitute for rail, will initially experience somewhat faster growth. A sharp increase in road freight, which has five times greater negative externalities than rail, would lead to significant external costs in the long term. The total cumulative net negative economic impact without additional rail capacity would range from EUR 400 to 1370 million under different scenarios of throughput dynamics in the port of Koper [89]. 


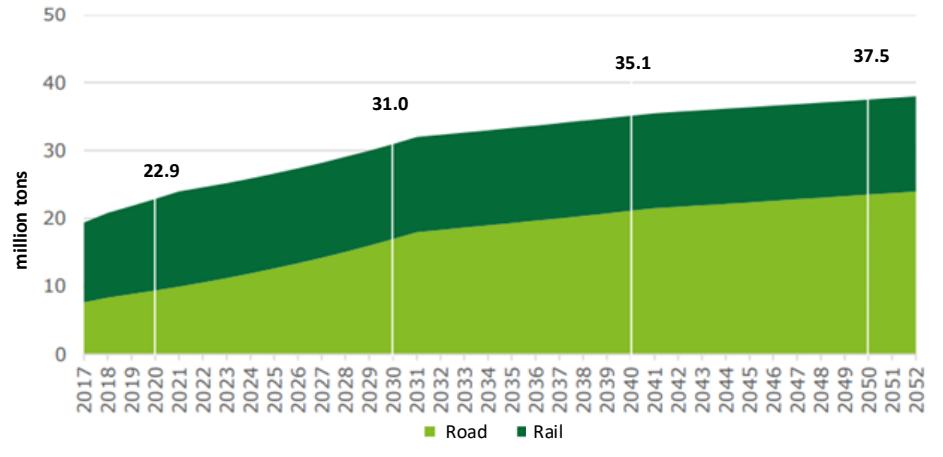

(a)

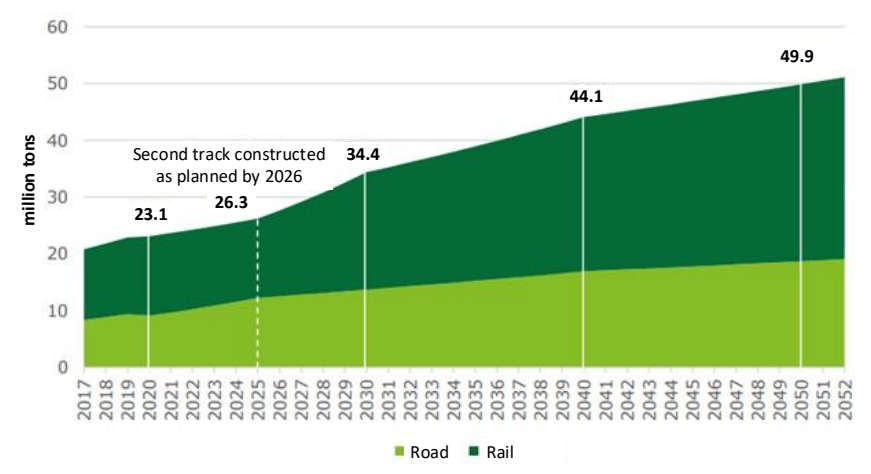

(b)

Figure 2. Forecasted volume and distribution of freight modes for the port of Koper if second rail track is: (a) not constructed, (b) constructed (in M tons). Source: [78].

\subsection{Port Gates}

Many ports attempt to reduce a port's landside congestion by increasing gate lanes and flattening the peaks of incoming trailer traffic [67]. Luka Koper has moved its gates several times throughout its history to avoid heavy truck traffic through the city. The port's current main gate, and the only port gate until May 2019, was built in the 1980s when the port had a total throughput of about 3 million tons distributed between road and rail. Today, about 250,000 trucks pass through this gate annually, carrying about 6 million tons of cargo, as the new gate only accounts for about $25 \%$ of the traffic, or about 2 million tons of cargo carried by road. The third gate is in the final stages of construction and is going through the process of obtaining an operating permit. Once operational, this new gate should accommodate about $50 \%$ of all trucks, which means that much of the truck traffic, about $75 \%$, will be off the city streets.

The main gate and the second gate have two lanes for entry and two lanes for exit from the port. Under normal conditions, one lane is used for empty trucks and the second for loaded trucks. Luka Koper has installed a separate gate at the container terminal, which is used as a pre-gate system to avoid congestion at the port's main gates.

The main gate is since recently opened $24 \mathrm{~h}$ a day, while the second gate (Sermin Gate) is open from 6 a.m. to 10 p.m. Monday to Friday and 6 a.m. to 3 p.m. on Saturdays.

Both gates can handle any type of cargo, the second gate being mainly for the second pier where dry bulk cargo is handled, while the main gate is mainly (but not only) used for containers.

\subsubsection{Road Port Access}

The main connection between the port of Koper and Slovenian highway system is through the Bertoki entrance, as can be seen from Figure 3.

The port can also be reached by a $2.5 \mathrm{~km}$ four-lane road (see Figure 5), but nowadays this is only a secondary route that passes shopping and commercial areas and is only used when the main access road is obstructed for some reason, such as an accident or maintenance work. Until 2008 and the construction of the Bertoki entrance, it was the only road connecting the port with the highways. 


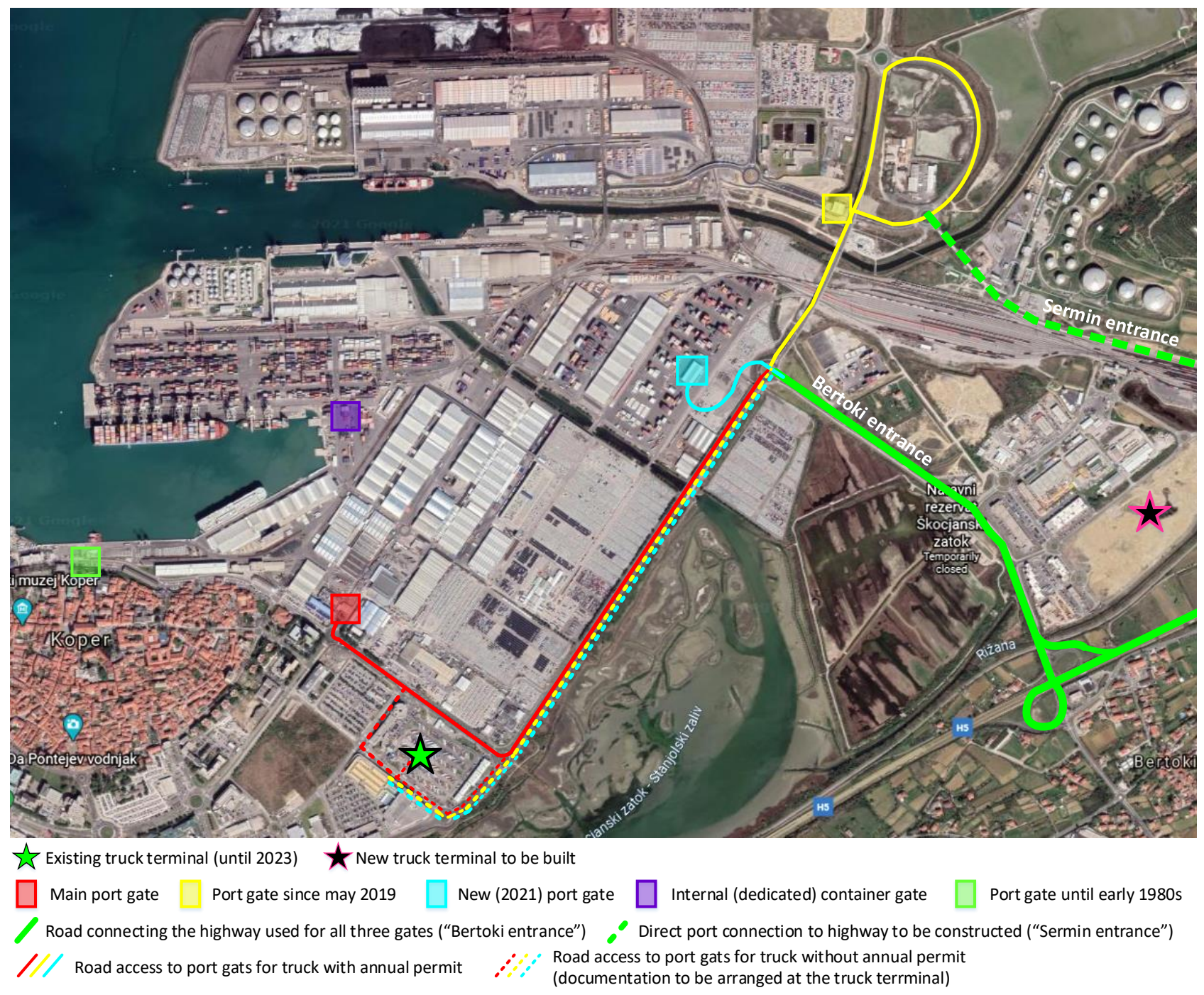

Figure 3. Road access to the port of Koper. Source: Authors, based on Google Earth photo.

\subsubsection{Port Gate Procedures}

One of the most important port-related traffic mitigation measures relates to reducing idle trucks at port gates [24]. For this reason, Luka Koper has introduced longer opening hours and the Vehicle Booking System (VBS), an online platform for making and processing truck appointments, checking cargo status and schedules, recording truck entries into the port, and checking the validity of annual permits to enter the port [90].

The use of VBS is mandatory since the end of November 2019 and the trucks without VBS appointment are turned away. The conditions for entering the port are a confirmed booking slot (the slot has a tolerance or "buffer" entry/exit time $\pm 1 \mathrm{~h}$ ), arrival at the agreed slot, a valid driver's permit (annual or one-off) and a prior or one-off purchase of a road charge [90].

Prior to entering the port, each truck must pay a toll at the truck terminal and obtain the required documentation, unless the annual fee is covered or the truck is transporting live livestock, in which case the vehicle is cleaned, washed, and disinfected immediately prior to entering the port [90].

\section{Port-Related Truck Traffic in Koper and Its Negative Externalities}

The full marginal cost of additional truck traffic is: (a) private costs, which include vehicle operating costs and own congestion costs; (b) infrastructure costs, which include capital and maintenance costs; and (c) non-internalized external or social costs, which 
include congestion costs, accident costs, and environmental costs from noise and emissions [91].

We focused on the external costs of emissions and congestion and roadway damage. The roads studied do not pass residential areas, and we have no data on accidents on these roads.

\subsection{Estimation of Port-Related Traffic Flows on Local Roads}

The number of trucks serving the port of Koper was estimated based on total port throughput, truck capacity and land transport modal split, and provides a bit lower numbers than the exact ones are when available. Our estimate of port-related truck traffic, presented in the Figure 4, is highly correlated with traffic on the last section of highway towards Koper $(r=0.882)$.

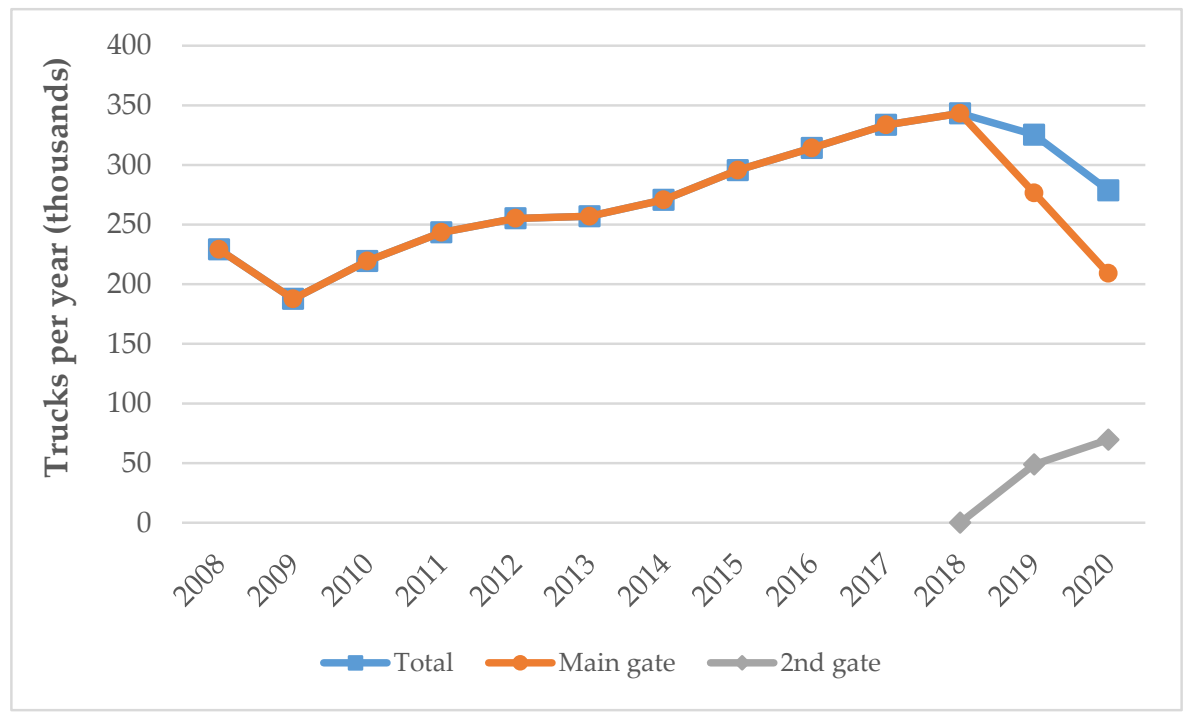

Figure 4. Estimated number of trucks due to port activities. Source: Authors.

The current main access from the Slovenian highway system to the port is via the $1.5 \mathrm{~km}$ two-lane Bertoki entrance. A small roundabout with an inner radius of only $20 \mathrm{~m}$ then diverts traffic towards the main gate, truck terminal or second gate, as shown in Figure 5. Most of the route from the roundabout towards the main gate and truck terminal is four lanes.

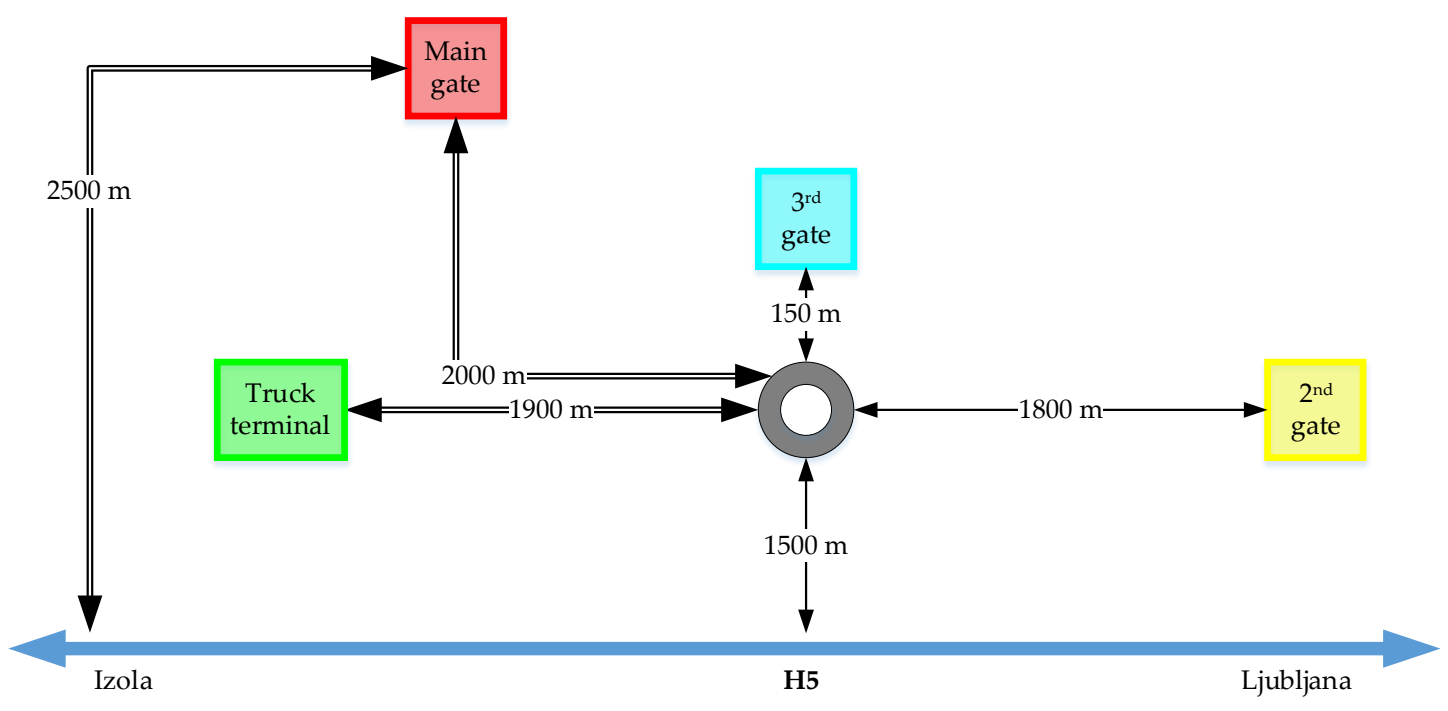

Figure 5. Schematic representation of port-related truck routes in Koper. Source: Authors. 
Truck traffic has increased greatly on Slovenian roads over the past decade, and it has also increased on the roads around the port as can be seen from Figure 6. It now accounts to around 2.5 million $\mathrm{km}$ per year. The official traffic records do not allow to verify the structure of traffic flows on different roads in Koper, but one of the sections towards the main gate has already reached a share of heavy goods traffic of more than $30 \%$. The problem of port-related traffic is aggravated by empty runs as double transactions are very rare in Koper.

We have approximated the volume of port-related traffic done on local roads each year. We used three different scenarios regarding the second gate and truck permits, namely (1) no trucks have annual permits, (2) half of the trucks have annual permits, and (3) all trucks have annual permits. Opening of the second gate generates more total miles on local roads in all cases except the situation where all trucks have annual permits; however, roads closer to the city center are significantly relieved of port-related traffic with the opening of second gate. We based all calculations on the Scenario 2.

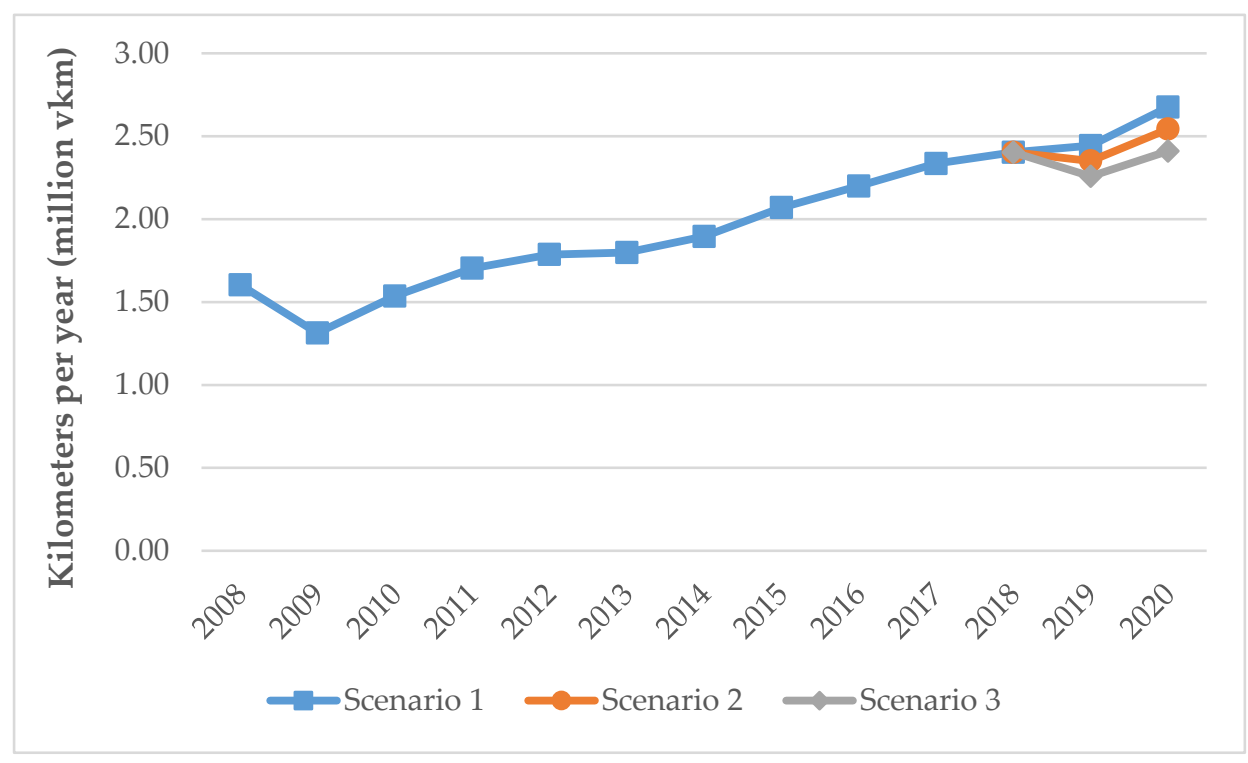

Figure 6. Estimated amount of port-related truck traffic on city roads. Source: Authors.

\subsubsection{Congestion on the Roads of Koper}

The 2015 study showed that the number of truck arrivals at the port of Koper was almost evenly distributed from Monday to Friday; however, truck arrivals during the day were very unevenly distributed with peaks in the morning between 6 and 8 a.m. and in the early afternoon, between 2 and 5 p.m. [92]. With the 24/7 opening hours of the main gate and the introduction of VBS, the distribution of truck arrivals throughout the day is almost even, with traffic peaks still usually occurring between 12 noon and 3 p.m. The situation of extreme congestion condition has not occurred since the introduction of VBS, while normal congestion occurs on regular basis on short section of the access road during peak period. These situations can be seen in the Figure 7. 


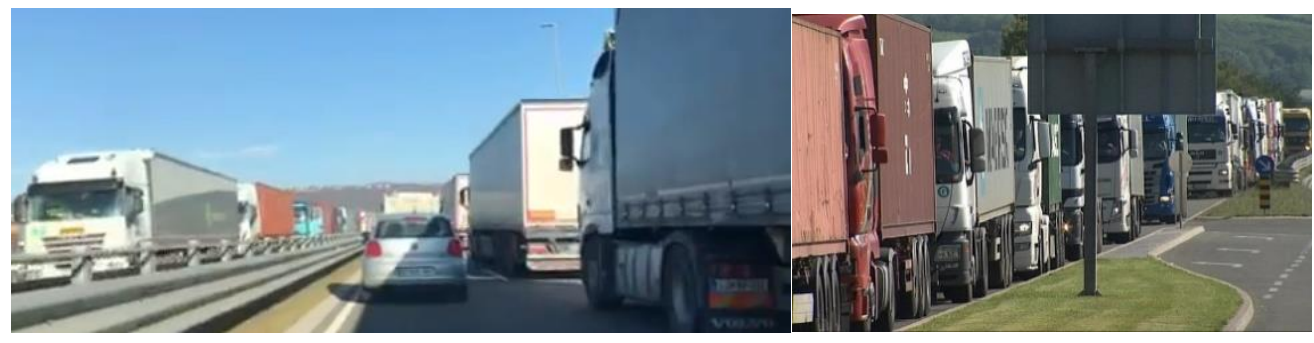

(a)

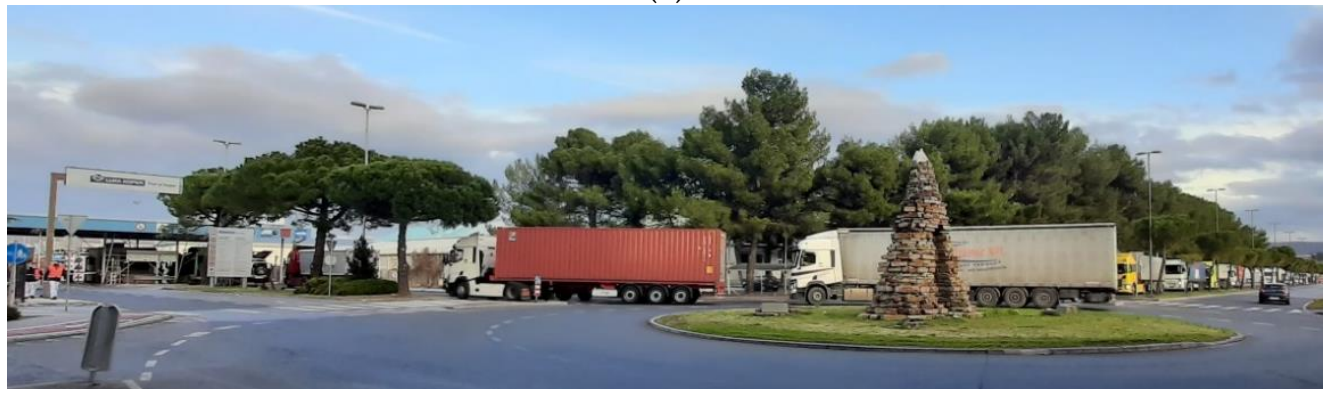

(b)

Figure 7. Extreme (a) and normal (b) congestion on the roads of Koper. Source: [93,94]; own source.

Highly congested roads are those on which the average annual daily traffic (AADT) is more than $50 \%$ of the estimated capacity for a given road category; for major roads, the estimated capacity is 30,000 vehicles per day [95]. Approximately 16,000 vehicles per day, about $20 \%$ of which are heavy trucks, currently use the Bertoki entrance and connecting roads. This means that it is possible to speak of an obstructed traffic flow, however, only in peak periods.

Congestion affects both travel speed and reliability of travel conditions. The direct costs of congestion include the cost of travel time delay imposed on users, the cost of excessive fuel consumption in vehicle traffic and the associated cost of emissions due to excessive fuel consumption.

We used the average EU marginal congestion costs on main urban roads for articulated trucks and for personal cars for free flow and near capacity conditions as calculated in the Update of the Handbook on External Costs of Transport [69]. The figures are presented in the Table 4 .

Table 4. Average EU marginal congestion costs in 2010 on main urban roads (EURct per vkm).

\begin{tabular}{cccc}
\hline & Free Flow & Near Capacity & Over Capacity \\
\hline Articulated truck & 1.2 & 141.1 & 219.9 \\
Car & 0.6 & 48.7 & 75.8 \\
\hline
\end{tabular}

Source: [69].

We then adjusted the provided values to Slovenia and to the selected year by using the following generalized Equation:

$$
E x t C \_ \text {Slovenia } a_{t}=E x t C \times \frac{G D P c \_S l o v e n i a_{t}}{24,400}
$$

where ExtC_Slovenia $a_{t}$ denotes any eternal costs calculated from the given figures ExtC in [69] and transformed for Slovenia in particular year $t$; GDPc_Slovenia $t$ is a value of GDP per capita in Slovenia in the year $t$; EUR 24,400 was the average EU GDP per capita in 2010.

We approximated the congestion costs only for the road sections shared with private cars, and based on the observations we defined periods with free traffic and near capacity periods; we omitted the over capacity situations as they were always only occasional, and 
since 2019 have not occurred. Majority of daily traffic occurs in a span of $15 \mathrm{~h}$, and most of the route is a four lane road, meaning that the congestion of trucks in most cases does not significantly affect the traffic of private cars. We used the average 90/10 free flow and near capacity (Free flow: volume (v)/capacity (c) $<0.25 ; 0.25<\mathrm{v} / \mathrm{c}<0.5 ; 0.5<\mathrm{v} / \mathrm{c}<0.75$; Near capacity: $0.75<\mathrm{v} / \mathrm{c}<1$; Over capacity: v/c $>1$ [67]) ratio for and 98/2 for private cars while taking into account the distance and period of day. We used the following equations to compute port-related congestion costs:

$$
\begin{aligned}
& C C_{-} \text {trucks } s_{t}=\frac{0.9 \times F F_{-} \text {trucks } s_{t} \times \text { trucks_km }_{t}+0.1 \times N C_{-} \text {trucks } s_{t} \times \text { trucks_km } m_{t}}{100} \\
& C C \_ \text {cars } t=\frac{0.02 \times N C_{-} \text {cars } s_{t} \times c a r s \_k m_{t}}{100}
\end{aligned}
$$

where CC_trucks $s_{t}$ and CC_cars C $_{t}$ denote the port-related congestion costs in the year $t$; $F F \_t r u c k s_{t}$ denotes value of free flow marginal costs for articulated trucks in Slovenia in the selected year $t$; $N C_{-}$trucks $_{t}$ and $N C_{-}$cars $s_{t}$ denote values of near capacity marginal costs for articulated trucks and private cars in Slovenia in the selected year $t$; trucks_kmt and cars_km $m_{t}$ denote amount of kilometers done on the shared road in the year $t$ by a selected group of vehicles; $\alpha, \beta$ and $\gamma$ are the parameters of traffic flow, in our case $\alpha=0.9, \beta=0.1$ and $\gamma=0.02$.

We skipped to include the congestion costs of private cars in free flow as this is not linked to port-related traffic.

The results are presented in the Table 5.

Table 5. Estimated port-related congestion costs.

\begin{tabular}{cccc}
\hline & Trucks & Personal Cars & Total \\
\hline 2008 & 193,918 & 262,359 & 456,278 \\
2009 & 150,341 & 248,386 & 398,727 \\
2010 & 175,741 & 248,260 & 424,002 \\
2011 & 198,268 & 252,498 & 450,766 \\
2012 & 203,005 & 248,492 & 451,497 \\
2013 & 205,214 & 250,670 & 455,883 \\
2014 & 222,979 & 253,395 & 476,374 \\
2015 & 251,211 & 276,769 & 527,980 \\
2016 & 277,724 & 289,980 & 567,704 \\
2017 & 313,351 & 310,008 & 623,359 \\
2018 & 342,877 & 344,310 & 687,187 \\
2019 & 326,974 & 365,462 & 692,436 \\
2020 & 259,036 & 347,304 & 606,340 \\
\hline Sum & $\mathbf{3 , 1 2 0 , 6 3 9}$ & $\mathbf{3 , 6 9 7 , 8 9 3}$ & $\mathbf{6 , 8 1 8 , 5 3 2}$ \\
\hline
\end{tabular}

Source: Authors.

\subsubsection{Emissions from Port-Related Traffic}

Although heavy trucks represent a small fraction of the total vehicle fleet, they have been identified as one of the most important contributors to air pollution [96].

The cost of air pollution is estimated by multiplying the amount of pollutants emitted by vehicles by the unit cost values of each pollutant. Air pollution from trucks is divided into primary pollution (emitted directly into the atmosphere) and secondary pollution (results from chemical reactions between pollutants in the atmosphere). Primary pollutants include volatile organic compounds (VOC), carbon monoxide (CO), and nitrogen oxides (NOx) as directly emitted pollutants and particulate matter (PM10) as an indirectly produced pollutant. Emissions are related to the vehicle's emission standard and fuel consumption, which has been stagnant for heavy trucks for years; on average it is around 35 l/100 km [97], but depends also on load and on speed as can be seen in Figure 8. 


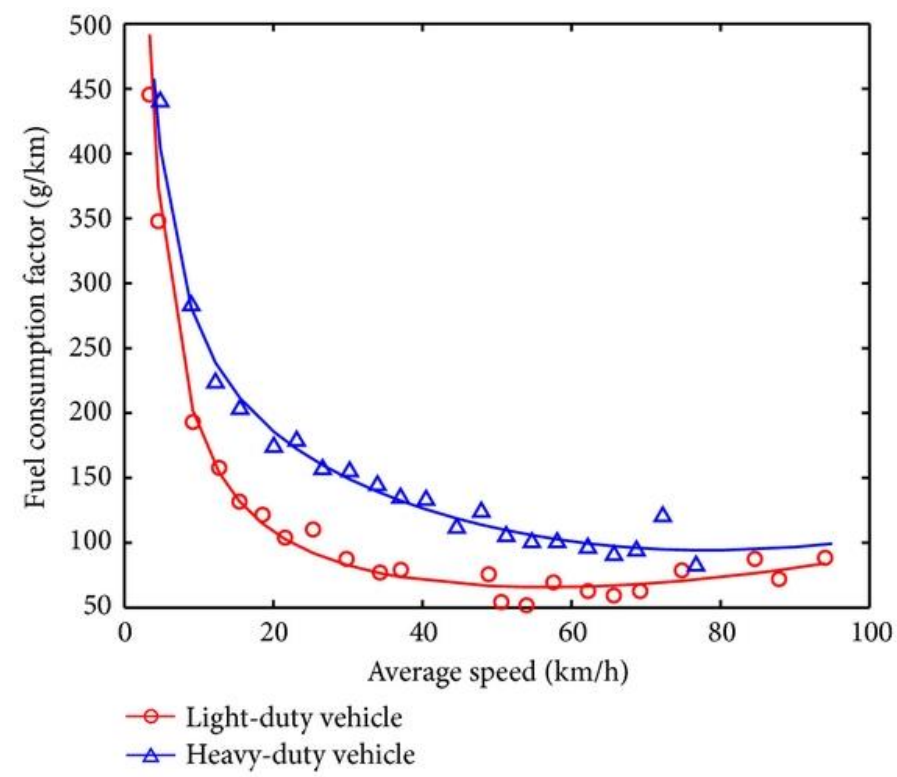

Figure 8. Speed related fuel consumption of commercial vehicles. Source: [35].

Traffic congestion increases fuel consumption and thus air emissions; however, our understanding of the impact of air pollution from road congestion is limited [98]. Congestion increases fuel consumption and emissions due to repeated stop and go activities, while idling increases engine maintenance costs, shortens engine life, and affects driver health and well-being through increased noise levels and reduced air quality [99].

We used the data on air pollution costs for heavy trucks as reported in Korzhenevych et al. [69]. The publication [69] provides damage costs of main pollutants (PM2.5, NOx, NMVOC and $\mathrm{SO}_{2}$ ) from transport, in EUR per tonne for single EU countries; however, this is too demanding to apply in our case, as too many assumptions wold need to be used. Thus we took a simplified approach by using average air pollution costs in EU expressed in EURct/vkm for various types of vehicles on urban roads.

Since our period of interest is from 2008 to 2020, we used only heavy trucks with the Euro IV standard (introduced in October 2005) or better and distinguished between loaded and empty rides. Similarly, passenger cars with diesel and petrol engines with an engine capacity of 1.4 to 2.01 and EURO standard 3 or better were considered according to their market entry and fleet structure in Slovenia.

The original figures used are presented in Table 6.

Table 6. EU average air pollution costs on urban roads in 2010 (EURct per vkm) for passenger cars and heavy goods vehicles.

\begin{tabular}{ccccc}
\hline Personal Cars & EURO3 & EURO 4 & EURO 5 & EURO 6 \\
\hline Petrol (1.4-2.0 L) & 0.4 & 0.4 & 0.4 & 0.4 \\
Diesel (1.4-2.0 L) & 2.6 & 1.8 & 0.9 & 0.7 \\
\hline Articulated Trucks & & EURO IV & EURO V & EURO VI \\
\hline 14-20 t & & 7.2 & 6.8 & 2.0 \\
$34-40 \mathrm{t}$ & & 11.2 & 8.5 & 2.1 \\
\hline
\end{tabular}

Source: [69].

We transformed the figures from Table 6 to Slovenian circumstances by applying equation (1). We applied Scenario 2, and used the same free flow-near capacity ratio as in the first calculation. We added emissions from personal cars that were in estimated stop and go regime due to port-related truck traffic (2\%), and used factor 4 to calculate emissions for the near capacity and stop and go regime in comparison to normal free flow 
conditions for trucks and cars. We then averaged the values according to the approximated fleet structure for trucks (EURO standard introduction) and private cars (EURO standard introduction and engine type). The results are shown in Table 7.

Table 7. Estimated emissions from port-related truck traffic.

\begin{tabular}{cccc}
\hline & Trucks & Personal Cars & Total \\
\hline 2008 & 147,442 & 32,938 & 180,380 \\
2009 & 101,470 & 30,555 & 132,025 \\
2010 & 118,613 & 28,172 & 146,786 \\
2011 & 133,817 & 25,789 & 159,606 \\
2012 & 137,014 & 24,722 & 161,737 \\
2013 & 138,505 & 23,557 & 162,062 \\
2014 & 116,096 & 21,840 & 137,937 \\
2015 & 130,796 & 21,798 & 152,594 \\
2016 & 144,600 & 20,619 & 165,219 \\
2017 & 163,150 & 19,099 & 182,249 \\
2018 & 178,523 & 19,640 & 198,162 \\
2019 & 175,934 & 17,390 & 193,324 \\
2020 & 142,592 & 17,390 & 159,981 \\
\hline Sum & $\mathbf{1 , 8 2 8 , 5 5 2}$ & $\mathbf{3 0 3 , 5 0 9}$ & $\mathbf{2 , 1 3 2 , 0 6 1}$ \\
\hline
\end{tabular}

Source: Authors.

\subsubsection{Pavement Deterioration}

Pavement deterioration is a process that involves various deterioration phenomena. Factors that influence pavement deterioration include vehicle mass, number of axles, axle configurations, wheel assemblies, and tire characteristics [45]. Moreover, the dynamic loading of heavy vehicles extremely accelerates pavement degradation [46].

The Bertoki entrance, built in 2008, was completely destroyed by heavy truck traffic by 2018 (see Figure 9); paradoxically, this road was never planned for heavy trucks and therefore was not built to accommodate them. The $3 \mathrm{~km}$ long two-lane road with three roundabouts and an attached viaduct, which cost around EUR 31 million, was only cosmetically repaired in 2018; the work lasted only around ten days and cost around EUR 180,000. Road damage is already visible again, and the forecast is that the number of heavy trucks on this road will double by 2030 .
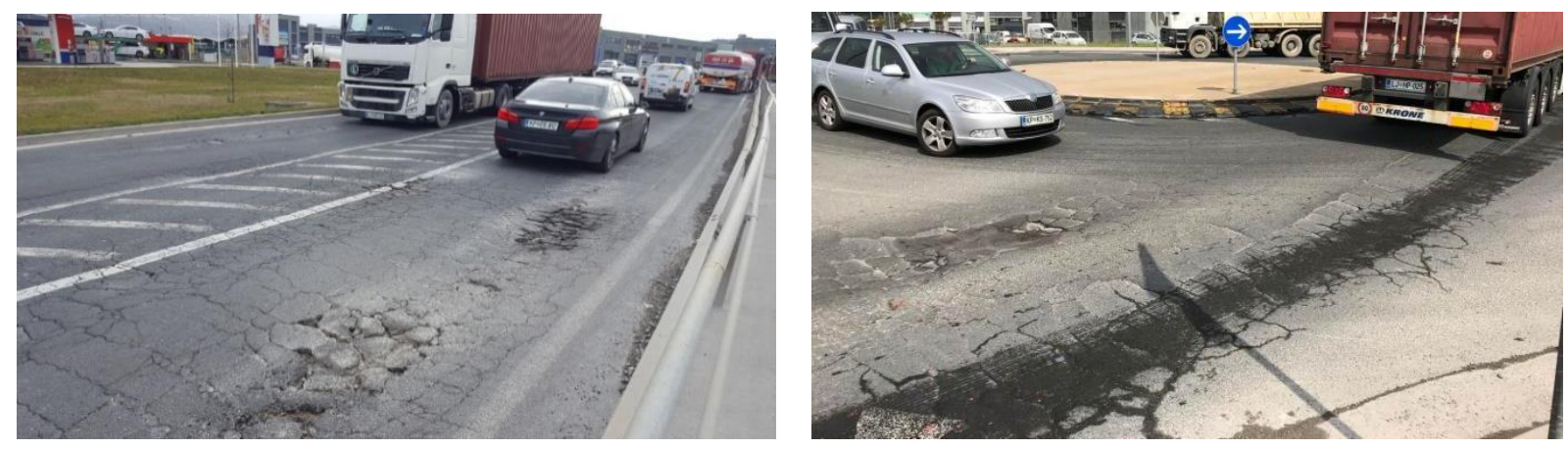

Figure 9. Bertoki entrance road before repair works. Source: [100].

In our approximation, we used simple static capacity of the vehicles and the number of axles. A generous approximation (the average passenger car with mass of two tons) suggests that if we convert port-related heavy traffic into passenger cars, we arrive at the astonishing figure of more than 12 million cars per day. 


\section{Discussion}

The port of Koper's throughput increased at an average annual growth rate (AAGR) of $7.0 \%$ between 2009 and 2018. In 2019, for the first time in more than a decade, the port's throughput decreased by more than $5 \%(5.2 \%)$; general cargo decreased by $16 \%$ and dry bulk by more than $17 \%$, while container traffic (expressed in the number of TEUs) decreased by $3 \%$.

When throughput declined in 2009, it was a global phenomenon due to the global economic crisis (similar to 2020), but the decline in 2019 was somewhat specific. The decrease in total throughput was also recorded in other ports of the Northern Adriatic; in Trieste by about $1 \%$ and in Rijeka by as much as $15 \%$, but both ports recorded growth in container traffic in terms of the number of units handled (Trieste by $8.9 \%$ and Rijeka by $17.3 \%$ ). Rijeka also recorded a $17.2 \%$ increase in general cargo handled, while Trieste recorded a 3.1\% increase in dry bulk. Although Koper continues to have the largest volume of these three cargo types among all North Adriatic ports, events in 2019 may indicate a reversal of the trend and it is necessary to determine the reasons for the shift of cargo to other ports in the region.

It is common that when a corridor becomes less responsive due to congestion, traffic moves to other end nodes [101]. Congestion can occur on any part of the corridor over which the port authority has no control; however, in 2019, neither road nor rail connections from the port of Koper were optimal. In such a case, the port authority plays an important role, but cannot do much without the support of local and national authorities.

Luka Koper has been trying to build a second port gate since 2007 to remove portrelated traffic from the city center and has constructed necessary in-port road infrastructure and reorganized port traffic adequately at the cost of around EUR 8 million. This gate had to be coupled with the $1.4 \mathrm{~km}$ long and EUR 7 million worth dedicated road connecting the port directly to the highway (Sermin entrance on Figure 3). However, due to various complications beyond Luka Koper control, one gate did not become operational until 2019, while the second has yet to be opened, and no dedicated road was built due to the archaeological remains found on the site, which would cost an estimated EUR 12 million to excavate.

The Bertoki entrance, built in 2008, has become a bottleneck and was supposed to be upgraded to a four-lane road in 2018; however, nothing has been done so far. According to unofficial estimates, EUR 5-7 million per kilometer will be spent on two additional lanes and the reconstruction of the existing lanes. Hopefully, it will be reconstructed in a way it will be able to accommodate immense port-related truck traffic.

The new truck terminal is to be built at the Bertoki entrance and will cover more than 90,000 square meters. It will cost around EUR 5 million and will be co-financed by the Connecting Europe Facility with $51 \%$. At the suggestion of Luka Koper, the state already approved a spatial plan for this terminal eleven years ago. Once completed, it will be able to accommodate around 300 trucks, which is 120 more than the existing terminal. The existing truck terminal needs to be relocated by 2023 as the municipality has new plans with this area. Once new terminal is up and running, trucks will not have to go to city center and most of the port's truck traffic will go through the new port gates. The distances to be covered will be shorter; however, without the construction of the Sermin entrance, all traffic will continue to go through the Bertoki entrance.

Luka Koper is expanding its capacity for the expected increase of transhipment, taking into account the environment and the local community by introducing various operational measures, installing more environmentally friendly equipment and even considering the use of renewable energy sources [102]. However, the fact is that this is not enough to ensure the port's competitiveness, which Luka Koper is aware of, but local and state authorities are obviously not. Our very conservative estimation of external costs caused by port related truck traffic including only two elements suggests that in the period from 2008 to 2020 around EUR 9 million of congestion and air pollution costs occurred. 
The construction of the improved railway connection between the port and the hinterland is delayed, and many other sections along the corridor are also unsatisfactory. For almost 15 years, Luka Koper has been agitating for a different design of the port's road connection. It is clear that the existing main road connection will have to accommodate larger cargo flows in the years until the railway is built, of course, if the port is to retain an important position in the northern Adriatic. A dedicated road would reduce or even eliminate congestion on the roads around the city, and consequently reduce congestionrelated emissions. Emissions from trucks would occur in any case, but within the port, where Luka Koper could influence the optimization of flows. Last but not least, the Bertoki entrance, a road that is constructed on soft terrain, would be used largely or exclusively for passenger cars that currently count to more than 12,000 per day.

Reducing traffic congestion reduces mobile source emissions and can improve the competitiveness and productivity of local economies [103]. Empty truck trips caused by a lack of coordination between truck companies are responsible for a significant proportion of air emissions [42]. Actually, the cooperation between truck carriers is seen as the greatest opportunity to address the problem of empty rides; however, transport-logistic market in Slovenia is very fragmented and also the majority of freight is for foreign markets and the transport is organized by foreign companies. This fragmentation also reduces the possibility of the utilization of truck platooning to reduce emissions. On the other hand, Luka Koper can introduce more digitalized processes at its gates, to reduce the possibility of errors and shorten the time to enter the port. Currently, no automatic identification system are in use.

\section{Conclusions}

Today, ports must not only follow green growth strategies in developing port infrastructure and equipment, but also proactively work towards a cleaner and more efficient supply chain.

For more than a decade, Luka Koper has stressed the importance of establishing new port gates and building a suitable connecting road. However, due to complicated ownership and archaeological legacies on site, all projects were cancelled, delayed, or made more expensive. The consequences of non-strategic and non-coordinated planning, inaccurate preliminary site reconnaissance, and/or legislative slowness are being felt most acutely at Luka Koper; its development is inhibited and local residents are increasingly critical of port-related traffic because it disrupts their daily lives. However, also Luka Koper could have applied various digitalized solutions by now to ease and fasten gate procedures.

Urban congestion caused by port-related traffic originates at the interface between the port and the countryside [7]. Koper is a small city and distances are short; therefore, with over a thousand trucks per day to and from the port, congestion on the roads is inevitable. The inconveniently located and relatively small truck terminal and the non-optimized gate procedures only aggravate the congestion.

Zanne et al. [104] and Stojaković et al. [105] investigated whether hinterland connections could affect the operation of the Port of Koper, but the focus was mainly on rail. Now we can ask whether the cargo loss in 2019 is not due to the unreliable operation of the supply chain by road, which has its origin in insufficiently digitized and under capacitated port gates and road port accesses. Further research will aim to answer this question and will imply the use of discrete event simulations methods to port data.

Author Contributions: Conceptualization, M.Z., E.T., and B.B.; methodology, M.Z., E.T., and B.B.; formal analysis, M.Z. and B.B.; resources, E.T. and M.Z.; writing-original draft preparation, M.Z.; writing-review and editing, M.Z. and E.T.; visualization, M.Z.; supervision, E.T. All authors have read and agreed to the published version of the manuscript.

Funding: This research received no external funding.

Institutional Review Board Statement: Not applicable.

Informed Consent Statement: Not applicable. 
Data Availability Statement: Not applicable.

Conflicts of Interest: The authors declare no conflict of interest.

\section{References}

1. UNCTAD. Review of Maritime Transport; UNCTAD: Geneva, Switzerland, 2019.

2. Slack, B. Containerization, Inter-Port Competition and Port Selection. Marit. Policy Manag. 1985, 12, 293-303. [CrossRef]

3. Tongzon, J. Port choice determinants in a competitive environment. In International Association of Maritime Economists; IAME: Panama City, Panama, 2002.

4. Sdoukopoulos, E.; Boile, M. Port-Hinterland Concept Evolution: A Critical Review. J. Transp. Geogr. 2020, 86. [CrossRef]

5. Parola, F.; Risitano, M.; Ferretti, M.; Panetti, E. The Drivers of Port Competitiveness: A Critical Review. Transp. Rev. 2017, 37, 116-138. [CrossRef]

6. Notteboom, T.; Rodrigue, J.-P. Port Regionalization: Towards a New Phase in Port Development. Marit. Policy Manag. 2005, 32. [CrossRef]

7. Merk, O. The Competitveness of Global Port-Cities: Synthesis Report; OECD: Paris, France, 2013.

8. Zhao, Q.; Xu, H.; Wall, R.S.; Stavropoulos, S. Building a Bridge between Port and City: Improving the Urban Competitiveness of Port Cities. J. Transp. Geogr. 2017, 59, 120-133. [CrossRef]

9. Bergqvist, R.; Egels-Zandén, N. Green Port Dues-The Case of Hinterland Transport. Res. Transp. Bus. Manag. 2012, 5, 85-91. [CrossRef]

10. Castellano, R.; Ferretti, M.; Musella, G.; Risitano, M. Evaluating the Economic and Environmental Efficiency of Ports: Evidence from Italy. J. Clean. Prod. 2020, 271. [CrossRef]

11. Lam, J.S.; Notteboom, T. The Greening of Ports: A Comparison of Port Management Tools Used by Leading Ports in Asia and Europe. Transp. Rev. 2014, 34, 169-189. [CrossRef]

12. Acciaro, M.; Ghiara, H.; Cusano, M. Energy Management in Seaport: A New Role for Port Authorities. Energy Policy 2014, 71, 4-12. [CrossRef]

13. Iris, Ç.; Lam, J.S.L. A review of energy efficiency in ports: Operational strategies, technologies and energy management systems. Renew. Sustain. Energy Rev. 2019, 112, 170-182. [CrossRef]

14. Androjna, A.; Twrdy, E. Cyber threats to maritime critical infrastructure. In Cyber Terrorism and Extremism as Threat to Critical Infrastructure Protection; Ministry of Defence Republic of Slovenia: Ljubljana, Slovenia, 2020.

15. Van der Lugt, L.; Dooms, M.; Parola, F. Strategy Making by Hybrid Organizations: The Case of the Port Authority. Res. Transp. Bus. Manag. 2013, 8, 103-113. [CrossRef]

16. Van den Berg, R.; De Langen, P.W. Hinterland Strategies of Port Authorities: A Case Study of the Port of Barcelona. Res. Transp. Econ. 2011, 33, 6-14. [CrossRef]

17. Trozzi, C.; Vaccaro, R. Environmental Impact of Port Activities. In Proceedings of the Second International Conference PORTS 2000 Maritime Engineering and Ports; WIT Press: Barcelona, Spain, 2000. [CrossRef]

18. Gonzalez Aregall, M.; Bergqvist, R.; Monios, J. A Global Review of the Hinterland Dimension of Green Port Strategies. Transp. Res. Part D 2018, 59, 23-34. [CrossRef]

19. Kong, Y.; Liu, J. Sustainable Port Cities with Coupling Coordination and Environmental Efficiency. Ocean Coast. Manag. 2021, 205. [CrossRef]

20. Yu, L.; Xu, P.; Shi, J.; Chen, J.; Zhen, H. Driving Mechanism of Port-City Spatial Relation Evolution from an Ecological Perspective: Case Study of Xiamen Port of China. Sustainability 2020, 12, 2857. [CrossRef]

21. Verhoeven, P. A Review of Port Authority Functions: Towards a Renaissance? Marit. Policy Manag. 2010, 37. [CrossRef]

22. Ferrari, C.; Parola, F.; Gattorna, E. Measuring the Quality of Port Hinterland Accessibility: The Ligurian Case. Transp. Policy 2011, 18, 382-391. [CrossRef]

23. Ng, A.K.Y.; Ducruet, C.; Jacobs, W.; Monios, J.; Notteboom, T.; Rodrigue, J.-P.; Slack, B.; Tam, K.; Wilmsmeier, G. Port Geography at the Crossroads with Human Geography: Between Flows and Spaces. J. Transp. Geogr. 2014, 41, 84-96. [CrossRef]

24. Merk, O.; Notteboom, T. Port Hinterland Connectivity; International Transport Forum: Paris, France, 2015.

25. Caballini, C.; Sacone, S.; Saeednia, M. Cooperation among Truck Carriers in Seaport Containerized Transportation. Transp. Res. Part E 2016, 93, 38-56. [CrossRef]

26. Szakonyi, M. Vancouver Truck Appointment Evolution Shows Challenges for US Ports. The Journal of Commerce Online. 14 March 2017. Available online: https:/ / www.joc.com/trucking-logistics/drayage/vancouver-truck-appointment-evolution-showschallenges-us-ports_20170314.html (accessed on 11 February 2021).

27. Harrison, R.M.; Van Vu, T.; Jafar, H.; Shi, Z. More Mileage in Reducing Urban Air Pollution from Road Traffic. Environ. Int. 2021, 149. [CrossRef]

28. Lao, J.; Song, H.; Wang, C.; Zhou, Y.; Wang, J. Reducing Atmospheric Pollutant and Greenhouse Gas Emissions of Heavy Duty Trucks by Substituting Diesel with Hydrogen in Beijing-Tianjin-Hebei Shandong Region, China. Int. J. Hydrogen Energy 2020. [CrossRef]

29. Cao, X.; Feng, S.; Shen, X.; Li, X.; Yao, X.; Zhiliang, Y. The Effects of Biodiesel Blends on Real-World Carbonyl Emissions from Diesel Trucks. Atmos. Environ. 2020, 238. [CrossRef] 
30. Anderhofstadt, B.; Spinler, S. Preferences for Autonomous and Alternative Fuel-Powered Heavy-Duty Trucks in Germany. Transp. Res. Part D 2020, 79. [CrossRef]

31. Chandra, S.; Nguyen, A. Freight Truck Emissions Reductions with Connected Vehicle Technology: A Case Study with I-710 in California. Case Stud. Transp. Policy 2020, 8, 920-927. [CrossRef]

32. Johansson, O. Optimal Road-Pricing: Simultaneous Treatment of Time Losses, Increased Fuel Consumption, and Emissions. Transp. Res. Part D Transp. Environ. 1997, 2, 77-87. [CrossRef]

33. Rosero, F.; Fonseca, N.; Lopez, J.-M.; Casanova, J. Effects of Passenger Load, Road Grade, and Congestion Level on Real-World Fuel Consumption and Emissions from Compressed Natural Gas and Diesel Urban Buses. Appl. Energy 2021, 282. [CrossRef]

34. Liu, H.; Kim, D. Simulating the Uncertain Environmental Impact of Freight Truck Shifting Programs. Atmos. Environ. 2019, 214. [CrossRef]

35. Song, Y.-y.; Yao, E.-j.; Zuo, T.; Lang, Z.-f. Emissions and Fuel Consumption Modeling for Evaluating Environmental Effectiveness of ITS Strategies. Discret. Dyn. Nat. Soc. 2013. [CrossRef]

36. Rodrigues Teixeira, A.C.; Rocha Borges, R.; Gerber Machado, P.; Mouette, D.; Dutra Ribeiro, F.N. PM Emissions from Heavy-Duty Trucks and Their Impacts on Human Health. Atmos. Environ. 2020, 241. [CrossRef]

37. Gonzalez-Barcala, F.; Pertega, S.; Garnelo, L.; Castro, T.P.; Sampedro, M.; Lastres, J.S.; Gonzales, S.J.; Bamonde, L.; Valdes, L.; Silvarrey, A.L. Truck Traffic Related Air Pollution Associated with Asthma Symptoms in Young Boys: A Cross-Sectional Study. Public Health 2013, 127, 275-281. [CrossRef]

38. Krzyzanowski, M. Health Effects of Transport-Related Air Pollution; World Health Organisation: Copenhagen, Denmark, 2005.

39. Bilbao-Ubillos, J. The Costs of Urban Congestion: Estimation of Welfare Losses Arising from Congestion on Cross-Town Link Roads. Transp. Res. Part A 2008, 42, 1098-1108. [CrossRef]

40. Fan, L.; Wilson, W.W.; Dah, B. Congestion, Port Expansion and Spatial Competition for US Container Ports. Transp. Res. Part E 2012, 48, 1121-1136. [CrossRef]

41. Struyf, E.; Sys, C.; Van de Voorde, E.; Vanelslander, T. Calculating the Cost of Congestion to Society: A Case Study Application to Flanders. Res. Transp. Bus. Manag. 2020. [CrossRef]

42. Schulte, F.; Lalla-Ruiz, E.; González-Ramírez, R.G.; Voß, S. Reducing Port-Related Empty Truck Emissions: A Mathematical Approach for Truck Appointments with Collaboration. Transp. Res. Part E 2017, 195-212. [CrossRef]

43. Kulauzović, B.; Nosaka, T.P.; Jamnik, J. Relationship between weight of the heavy trucks and traffic noise pollution in the viewpoint of feasibility of fines for exceeded noise-A case study. In 8th Transport Research Arena TRA 2020; Finnish Transport Safety Agency (Trafi): Helsinki, Finland, 2020.

44. Freitas, E.F.; Martins, F.F.; Oliveira, A.; Segundo, I.R.; Torres, H. Traffic noise and pavement distresses: Modelling and assessment of input parameters influence through data mining techniques. Appl. Acoust. 2018, 138, 147-155. [CrossRef]

45. Schmidt, F.; Glaeser, K.P.; Hornych, P.; Piau, J.M.; Jacob, B. Impacts from Truck Traffic on Road Infrastructure. HAL. 2013. Available online: https:/ / hal.archives-ouvertes.fr/hal-00948899 (accessed on 15 January 2021).

46. Liu, J. Research on the Damage of Heavy Vehicles to the Pavement. In Proceedings of the 3rd International Conference on Management, Education, Information and Control-MEICI 2015; Atlantis Press: Shenyang, China, 2015.

47. Pircher, M.; Lechner, B.; Mariani, O.; Kammersberger, A. Damage Due to Heavy Traffic on Three RC Road Bridges. Eng. Struct. 2011, 33, 3755-3761. [CrossRef]

48. Russo, F.; Musolino, G. Quantitative characteristics for port generations: The Italian case study. Int. J. Transp. Dev. Integr. 2020, 4, 103-112. [CrossRef]

49. Giuliano, G.; O'Brien, T. Reducing Port-Related Truck Emissions: The Terminal Gate Appointment System at the Ports of Los Angeles and Long Beach. Transp. Res. Part D Transp. Environ. 2007, 12, 460-473. [CrossRef]

50. Chen, G.; Govindan, K.; Yang, Z.-Z.; Choi, T.-M.; Jiang, L. Terminal Appointment System Design by Non-Stationary M(t)/Ek/c(t) Queueing Model and Genetic Algorithm. Int. J. Prod. Econ. 2013, 146, 694-703. [CrossRef]

51. Zhang, X.; Zeng, Q.; Chen, W. Optimization model for truck appointment in container terminals. In Proceedings of the ProcediaSocial and Behavioral Sciences (13th COTA International Conference of Transportation Professionals—CICTP 2013); Elsevier: Shenzhen, China, 2013; Volume 96, pp. 1938-1947.

52. Phan, M.-H.; Kim, K.H. Collaborative truck scheduling and appointments for trucking companies and container terminals. Transp. Res. Part B Methodol. 2016, 86, 37-50. [CrossRef]

53. Jin, Z.; Lin, X.; Zang, L.; Liu, W.; Xiao, X. Lane Allocation Optimization in Container Seaport Gate System Considering Carbon Emissions. Sustainabilty 2021, 13, 3628. [CrossRef]

54. Guan, C.; Liu, R. Container terminal gate appointment system optimization. Marit. Econ. Logist. 2009, 11, 378-398. [CrossRef]

55. Meersman, H.; Voorde, E.V.; Vanelslander, T. Port congestion and implications to maritime logistics. In Maritime Logistics: Contemporary Issues; Song, D., Panayides, P., Eds.; Emerald: Bingley, UK, 2012.

56. Morley, H.R. New Gates Help Slash Mobile Port Turn Times. The Journal of Commerce Online. 7 October 2019. Available online: https:/ / www.joc.com/port-news/us-ports/port-mobile/new-gates-help-cut-mobile-turn-times-20-percent_20191007 .html (accessed on 1 February 2021).

57. Minh, C.C.; Huynh, N. Optimal Design of Container Terminal Gate Layout. Int. J. Shipp. Transp. Logist. 2017, 9, 640-650. [CrossRef] 
58. Port Strategy. The Gate Keepers. Port Strategy Insight Port Executive. 2010. Available online: https:/ /www.portstrategy.com/ news101/port-operations/planning-and-design/gate-systems (accessed on 15 January 2021).

59. De la Peña Zarzuelo, I.; Freire Soeane, M.J.; Lopez Bermúdez, B. Industry 4.0 in the Port and Maritime Industry: A Literature Review. J. Ind. Inf. Integr. 2020. [CrossRef]

60. Chao, S.-L. Efficient port gate automation. Autom. Optim. 2017, 74, 30-31. Available online: https://www.porttechnology.org/ wp-content/uploads/2019/05/CHAO.pdf (accessed on 20 January 2021).

61. Henriksson, B.; Hong-Wei, L.; Hong-Liang, W. Increasing Terminal Capacity by $10 \%$-A Case Study in Yard Transformation. ABB. 2020. Available online: https://new.abb.com/news/detail/57450/increasing-terminal-capacity-by-10-a-case-study-inyard-transformation (accessed on 20 January 2021).

62. Bask, A.; Roso, V.; Andersson, D.; Hämäläinen, E. Development of Seaport-Dry Port Dyads: Two Cases from Northern Europe. J. Transp. Geogr. 2014, 39, 85-95. [CrossRef]

63. Beškovnik, B.; Zanne, M. Extended Gate Concept for Maritime Automobile Terminals. Naše More 2015, 45-52. [CrossRef]

64. Barboza, T.L.A. Long Beach Ports Approve Truck Fee Too Low to Clean Smog, Groups Charge. Los Angeles Times. 2020. Available online: https:/ / www.latimes.com/environment/story/2020-03-09/la-long-beach-ports-set-modest-truck-fee-criticized-asinsufficient-to-curb-smog (accessed on 21 January 2021).

65. AlRukaibi, F.; AlKheder, S.; AlMashan, N. Sustainable Port Management in Kuwait: Shuwaikh Port System. Asian J. Shipp. Logist. 2020, 36, 20-33. [CrossRef]

66. IMO. Port Emission Toolkit Guide No. 2: Development of Port Emission Reduction Strategies; GloMeep Project and the International Maritime Organization: London, UK, 2018.

67. Motono, I.; Furuichi, M.; Ninomiya, T.; Suzuki, S.; Fuse, M. Insightful observations on trailer queues at landside container terminal gates: What generates congestion at the gates? Res. Transp. Bus. Manag. 2016, 19, 118-131. [CrossRef]

68. Li, D.; Dong, J.-X.; Song, D.-P.; Hicks, C.; Singh, S.P. Optimal contract design for the exchange of tradable truck permits at multiterminal ports. Int. J. Prod. Econ. 2020. [CrossRef]

69. Korzhenevych, A.; Dehnen, N.; Bröcker, J.; Holtkamp, M.; Meier, H.; Gibson, G.; Varma, A.; Cox, V. Update of the Handbook on External Costs of Transport; Ricardo-AEA: London, UK, 2014.

70. Feng, L.; Notteboom, T. Peripheral Challenge by Small and Medium Sized Ports (SMPs) in Multi-Port Gateway Regions: The Case Study of Northeast of China. Pol. Marit. Res. 2013, 20, 55-66. [CrossRef]

71. Santos, S.; Rodrigues, L.L.; Branco, M.C. Online Sustainability Communication Practices of European Seaports. J. Clean. Prod. 2016, 112, 2935-2942. [CrossRef]

72. Alamoush, A.S.; Ballini, F.; Ölçer, A.I. Ports' Technical and Operational Measures to Reduce Greenhouse Gas Emission and Improve Energy Efficiency: A Review. Mar. Pollut. Bull. 2020, 160. [CrossRef]

73. Giuliano, G.; Linder, A. Motivations for Self-Regulation: The Clean Air Action Plan. Energy Policy 2013, 59, 513-522. [CrossRef]

74. Poulsen, R.; Ponte, S.; Sornn-Friese, H. Environmental Upgrading in Global Value Chains: The Potential and Limitations of Ports in the Greening of Maritime Transport. Geoforum 2018, 89, 83-95. [CrossRef]

75. Luka Koper. Management System in Luka Koper. 2021. Available online: https://www.luka-kp.si/eng/quality (accessed on 1 February 2021).

76. Luka Koper. Statistika Pretovora. 2021. Available online: https://www.luka-kp.si/slo/statistika-pretovora (accessed on 22 February 2021).

77. Luka Koper. Summary of Luka Koper d.d. and the Luka Koper Group Business Strategy until 2030 and the Company's and Group's Strategic Business Plan 2016-2020; Luka Koper: Koper, Slovenia, 2015.

78. Deloitte. Investicijski Program za Novo Železniško Progo Divača—Koper; Deloitte Svetovanje d.o.o.: Ljubljana, Slovenia, 2019.

79. SURS. Slovene Statistical Regions and Municipalities in Numbers. 2021. Available online: https://www.stat.si/obcine/en (accessed on 5 February 2021).

80. ZRSZ. Trg Dela_Stopnja Registrirane Brezposelnosti. 2021. Available online: https://www.ess.gov.si/trg_dela/trg_dela_v_ stevilkah/stopnja_registrirane_brezposelnosti (accessed on 5 February 2021).

81. Luka Koper. Letno Poročilo 2019; Luka Koper: Koper, Slovenia, 2020.

82. Luka Koper. Trajnostno Poročilo 2018; Luka Koper: Koper, Slovenia, 2019.

83. Luka Koper. Luški Vozli; Luka Koper: Koper, Slovenia, 2018.

84. Močnik, D.; Ivanc, B. Vpliv Pristaniške Dejavnosti Luke Koper na Gospodarstvo Slovenije, Obalno-Kraško Regijo in Slovensko Logistiko; Analitika GZS: Ljubljana, Slovenia, 2020.

85. Luka Koper. En evro Prodaje v Pristaniški Dejavnosti Ustvari še 3,3 Evre v Preostalem Gospodarstvu. 2020. Available online: https:/ / www.luka-kp.si/slo/novice/single/en-evro-prodaje-v-pristaniski-dejavnosti-ustvari-s-37229 (accessed on 17 February 2021).

86. ReNRP. Resolucija o Nacionalnih Razvojnih Projektih za Obdobje 2007-2023; Služba Vlade RS za razvoj: Ljubljana, Slovenia, 2006.

87. Slovenske železnice. Povzetek Letnega Poročila 2015; Slovenske železnice: Ljubljana, Slovenia, 2016.

88. Slovenske železnice. Letno Poročilo 2019; Slovenske železnice: Ljubljana, Slovenia, 2020.

89. Damijan, J.P. Ocena Bodočih Blagovnih Tokov Pristanišča Koper in Narodnogospodarskih Učinkov Različnih Variant Transportnih Povezav Pristanišča z Zalednimi Državami; Ljubljana Institute of Finance and Economics: Ljubljana, Slovenia, 2012. 
90. Luka Koper. Information for Truckers—Vehicle Booking System. Available online: https://www.luka-kp.si/eng/informationfor-truckers (accessed on 19 February 2021).

91. Berechman, J. Estimation of the Full Marginal Costs of Port Related Truck Traffic. Eval. Program Plan. 2009, 32, 390-396. [CrossRef] [PubMed]

92. HPC. Rethinking Container Terminal Management; HPC Hamburg Port Consulting GmbH: Hamburg, Germany, 2015.

93. Bertoški Vhod v Luko Koper: Z Dokumenti Razkrivamo, kdo Zavlačuje in Zakaj! 2017. Available online: https: / / www.regionalobala.si/novica/bertoski-vhod-v-luko-koper-z-dokumenti-razkrivamo-kdo-zavlacuje-in-zakaj (accessed on 19 February 2021).

94. Mavsar, E. Tovornjaki Okupirali Koper. 2021. Available online: https://www.rtvslo.si/lokalne-novice/tovornjaki-okupiralikoper/368422 (accessed on 19 February 2021).

95. DARS. Obremenjenost Cest. 2016. Available online: https://www.dars.si/Prometne_obremenitve (accessed on 19 February 2021).

96. Grigoratos, T.; Fontaras, G.; Giechaskiel, B.; Zacharof, N. Real World Emissions Performance of Heavy-Duty Euro VI Diesel Vehicles. Atmos. Environ. 2019, 201, 348-359. [CrossRef]

97. Delgado, O.; Rodríguez, F. $\mathrm{CO}_{2}$ Emissions and Fuel Consumption Standards for Heavy-Duty Vehicles in the European Union. International Council on Clean Transportation. 2018. Available online: https:/ theicct.org/publications/co2-emissions-and-fuelconsumption-standards-heavy-duty-vehicles-european-union (accessed on 27 February 2021).

98. Zhang, K.; Batterman, S. Air Pollution and Health Risks Due to Vehicle Traffic. Sci. Total Environ. 2013, 450-451, 307-316. [CrossRef] [PubMed]

99. Whistler, D. Fuel Economy 101. Fleet Own. 2011. Available online: https://www.fleetowner.com/running-green/fuel/article/21 660208/fuel-economy-101 (accessed on 1 March 2021).

100. V ponedeljek Pričetek Obnove Bertoške Vpadnice: Enosmerni Režim za vse, Dela Končana v Tednu dni. 2018. Available online: https:/ / regionalobala.si/novica/v-ponedeljek-pricetek-obnove-bertoske-vpadnice-enosmerni-rezim-za-vse-dela-koncanav-tednu-dni (accessed on 19 February 2021).

101. Rodrigue, J.-P.; Ducruet, C. The geography of transportation networks. In The Geography of Transport Systems; Rodrigue, J., Comtois, C., Slack, B., Eds.; Routledge: New York, NY, USA, 2013.

102. Zanne, M.; Twrdy, E. The Economic Feasibility of Port Air Emissions Reduction Measures: The Case Study of the Port of Koper. J. Econ. Bus. Rev. in press.

103. FHA. The Congestion Mitigation and Air Quality Improvement Program; Transportation Research Board: Washington, DC, USA, 2000.

104. Zanne, M.; Bajec, P.; Twrdy, E.; Stojaković, M. Can Hinterland Connections Cope with the Expanssion Plans of the Port of Koper? In IMSC 2012-Book of Proceedings; Faculty of Maritime Studies: Split, Croatia, 2012.

105. Stojaković, M.; Twrdy, E.; Zanne, M. The Railway Hinterland Connection-The Key Factor in the Development of North Adriatic Port. In Maritime Transport'14; Universitat Politècnica de Catalunya Barcelonatec: Barcelona, Spain, 2014. 